\title{
Psoriatic Arthritis and Diabetes Mellitus: A Narrative Review
}

\author{
Giacomo Dal Bello (D) - Paolo Gisondi · Luca Idolazzi • \\ Giampiero Girolomoni
}

Received: January 18, 2020 / Published online: April 18, 2020

(c) The Author(s) 2020

\begin{abstract}
Introduction: Psoriatic arthritis (PsA) is a chronic immune-mediated inflammatory spondyloarthropathy associated with psoriasis. PsA is frequently associated with metabolic disorders including, obesity, metabolic syndrome, and diabetes mellitus (DM). Type 2 DM is among the most common metabolic disorders, with a prevalence ranging from 2.4 to $14.8 \%$ in the general population.

Methods: We conducted a narrative review of the English-language studies from January 1989 to September 2019 investigating the risk of type 2 DM in patients with PsA, the pathogenic mechanism linking DM to PsA, and the effects on insulin sensitivity exerted by systemic therapies for PsA.
\end{abstract}

Results: The prevalence of type $2 \mathrm{DM}$ in patients with PsA ranges from 6.1 to $20.2 \%$,

Digital Features To view digital features for this article go to: https://doi.org/10.6084/m9.figshare.12073812.

G. Dal Bello $(\varangle)$ · P. Gisondi · G. Girolomoni Section of Dermatology, Department of Medicine, University of Verona, 37126 Verona, Italy e-mail: giacomo.dalbello@studenti.univr.it

L. Idolazzi

Section of Rheumatology, Department of Medicine, University of Verona, 37126 Verona, Italy generally higher when compared to the general population. The higher risk of DM is reported in women with more severe forms of PsA. Elevated serum levels of adipokines, including TNF- $\alpha$, which inhibits the autophosphorylation of the insulin receptor and suppresses the expression of glucose transporter 4, favor insulin resistance and could partially explain the association between PsA and DM. Moreover, adiponectin and omentin, with insulin-sensitizing and antiatherogenic properties, are decreased in patients with PsA. Some of the treatments for PsA could affect the glucose homeostasis. Systemic corticosteroids are known to impair insulin resistance, whereas apremilast (phosphodiesterase type 4 inhibitor) and TNF- $\alpha$ inhibitors could exert neutral effect or reduce the insulin-resistance. The role of IL-17 or IL-23 inhibitors has been marginally investigated.

Conclusions: Patients affected by PsA have a higher prevalence of type $2 \mathrm{DM}$ compared with the general population. The mechanism linking PsA with DM has not been completely clarified, but some of the principal mediators could be TNF- $\alpha$ and adipokine, especially adiponectin and omentin. Apremilast and TNF- $\alpha$ inhibitor may have a favorable effect and could be safely used in patients with DM.

Keywords: Adipokine; Anti-IL-17; Anti-TNF- $\alpha$; Apremilast; Diabetes mellitus; Diseasemodifying anti-rheumatic drug; Glucocorticoids; Omentin; Psoriatic arthritis 


\section{Key Summary Points}

\section{Why carry out this study?}

To provide a very brief background about psoriatic arthritis, a diffuse chronic immune-mediated inflammatory spondyloarthropathy associated with psoriasis, and diabetes mellitus, the most common metabolic disorders in the industrial world.

Find the epidemiological association and pathogenic mechanisms linking psoriatic arthritis and diabetes mellitus.

Consider the effect of therapies for psoriatic arthritis on diabetes mellitus.

\section{What was learned from the study?}

Patients affected by psoriatic arthritis have a higher prevalence of diabetes mellitus compared with the general population.

The pathogenic link between psoriatic arthritis and diabetes mellitus is not fully understood, but some of the principal mediators could be TNF- $\alpha$ and adipokine.

Biological therapies for psoriatic arthritis have a neutral effect on glucose homeostasis and could be safely used in patients with diabetes mellitus. It is possible that some new therapies, including apremilast and anti-TNF- $\alpha$, could improve diabetes mellitus based on their mechanism of action.

\section{INTRODUCTION}

Psoriatic arthritis (PsA) is a chronic immunemediated inflammatory spondyloarthropathy associated with psoriasis. The prevalence of PsA in the general population ranges from 0.06 to $1 \%$ [1], and its annual incidence ranges from 41 to 167 cases per 100,000 person-years [2, 3]. The manifestations of psoriasis usually precede arthritis by 10 years on average, although in $15 \%$ of cases arthritis and psoriasis occur simultaneously or PsA anticipates skin disease. PsA develops in $8-36.4 \%$ of patients with psoriasis, equally in men and women in Europe and North America [4-8]. The clinical manifestations of PsA include peripheral arthritis, axial involvement, enthesitis, or dactylitis [9]. Patients with PsA could also present nail disease and more rarely uveitis [10]. PsA generally presents as tendon and/or joint inflammation and swelling. Chronic inflammation can progress to new bone formation and irreversible joint damage with long-term disability. The most widely used diagnostic and classification criteria of PsA are the CASPAR criteria, which include evidence of current psoriasis (personal or family history of psoriasis), typical psoriatic nail dystrophy (including onycholysis, pitting, and hyperkeratosis), a negative test result for rheumatoid factor, dactylitis (either current or a history), and radiographic evidence of juxta-articular new bone formation of the hand or foot on plain radiographs [11]. PsA is frequently associated with metabolic disorders including obesity, metabolic syndrome, and diabetes mellitus (DM).

In this review, we discuss the prevalence of type 2 diabetes in patients with PsA. DM is among the most common metabolic disorders, with majority of patients (90-95\%) affected by type 2 DM [12]. Few studies investigate the association between type $1 \mathrm{DM}$ and other immune-mediated diseases including PsA, but they do not find any association [13]. According to the International Diabetes Federation, the estimated number of patients with DM in Europe in 2013 is 56.3 million $(6.2 \%$ of the total population), and prevalence varies from 2.4 to $14.8 \%$ among countries [14]. The prevalence of diabetes in USA is $9.4 \%$ [15], China $10.9 \%$ [16], India 8.3\% [17], and Canada 10\% [18]. Complications of DM account for increased morbidity, disability, and mortality. Microvascular complications include diabetic nephropathy, neuropathy, and retinopathy, and each of these are induced by chronic hyperglycemia via several mechanisms such as the production of advanced glycation end products (AGEs), the creation of a proinflammatory 
microenvironment, and the induction of oxidative stress $[19,20]$. Macrovascular complications include stroke, angina pectoris, myocardial infarction, and peripheral arteriopathy due to atherosclerosis [21]. The objective of the manuscript is to review the studies investigating the risk of DM in patients with PsA, the pathogenic mechanism linking DM to PsA, and the effects on insulin sensitivity exerted by systemic therapies for PsA.

\section{METHODS}

We carried out a narrative review of the Englishlanguage literature in the period ranging from January 1989 to January 2020 related to the epidemiologic association between PsA and type $2 \mathrm{DM}$, the pathogenic mechanisms linking PsA to DM, and the effects of systemic therapies for PsA on glucose homeostasis. The following databases were consulted: PubMed, Embase, Google Scholar, and ResearchGate. The research of articles was conducted by using the key term 'psoriatic arthritis' combined with each of the following: 'pathogenesis', 'comorbidities', 'cardiovascular disease', 'metabolic syndrome', 'arthritis', 'cytokine', 'adipokine', 'systemic treatment', 'methotrexate', 'leflunomide', 'sulfasalazine', 'apremilast', 'etanercept', 'adalimumab', 'infliximab', 'ustekinumab', 'secukinumab', 'ixekizumab', 'certolizumab', and 'guselkumab'. For each article, the type of study and endpoints were noted. Meta-analyses of randomized controlled studies were preferentially considered. If none existed, lower-evidence studies, such as cohort studies, case reports, and case-control studies were selected. Some additional sources were found by looking at the references of the articles identified during the initial search. This article is based on previously conducted studies and does not contain any studies with human participants or animals performed by any of the authors.

\section{THE EPIDEMIOLOGICAL ASSOCIATION BETWEEN PSORIATIC ARTHRITIS AND DIABETES MELLITUS}

The comparison with the general population showed that patients with PsA are more likely to have an increased prevalence of type $2 \mathrm{DM}$. A series of studies investigated the epidemiological association between PsA and DM. The prevalence of DM in patients with PsA ranges from 6.1 to $20.2 \%$. In more detail, the prevalence of DM in PsA cohort in North America, Hong Kong, Israel, Spain, and UK is $11.3-20.2 \%$, $18.6 \%, 15.3 \%$, 9.2-13.8\%, 6.1\%, respectively [12, 22-30] (Table 1).

Table 1 Studies investigating the prevalence of diabetes mellitus in patients with PsA

\begin{tabular}{llllll}
\hline $\begin{array}{l}\text { First author, year } \\
\text { of publication }\end{array}$ & County & Sample size & $\begin{array}{l}\text { Prevalence of diabetes } \\
\text { mellitus in the general } \\
\text { population (\%) }\end{array}$ & $\begin{array}{l}\text { Prevalence of diabetes } \\
\text { mellitus in patients } \\
\text { with PsA (\%) }\end{array}$ & $\begin{array}{l}\text { Type of } \\
\text { study }\end{array}$ \\
\hline Charlton, 2018 & UK & 6783 & 4.3 & 6.1 & Prospective study \\
Castañeda, 2015 & Spain & 2234 & 5.0 & 9.2 & Prospective study \\
Queiro, 2018 & Spain & 340 & 5.0 & 13.8 & Cross-sectional \\
Shah, 2017 & US & 186552 & 9.4 & 20.2 & Prospective study \\
Dreiher, 2013 & Israel & 1647 & 10.7 & 15.3 & Cross-sectional \\
Tam, 2008 & Hong Kong & 185 & 2.4 & 18.6 & Cross-sectional \\
\hline
\end{tabular}


Table 2 Studies investigating the risk of diabetes mellitus in patients with PsA

\begin{tabular}{|c|c|c|c|c|c|}
\hline $\begin{array}{l}\text { First author, year of } \\
\text { publication }\end{array}$ & County & $\begin{array}{l}\text { Sample } \\
\text { size }\end{array}$ & $\begin{array}{l}\text { Measure of } \\
\text { association }\end{array}$ & $\begin{array}{l}\text { Risk of diabetes mellitus in } \\
\text { patients with PsA }\end{array}$ & $\begin{array}{l}\text { Type of } \\
\text { study }\end{array}$ \\
\hline Eder, 2017 & Canada & 1305 & $\begin{array}{l}\text { Age-standardized } \\
\text { prevalence ratio }\end{array}$ & $1.43(95 \%$ CI $1.2-1.7)$ & $\begin{array}{l}\text { Cross } \\
\text { sectional }\end{array}$ \\
\hline Coto-Segura, 2013 & $\begin{array}{c}\text { UK, US, } \\
\text { China }\end{array}$ & 16,914 & OR & 2.18 (95\% CI $1.36-3.50)$ & $\begin{array}{l}\text { Meta- } \\
\text { analysis }\end{array}$ \\
\hline Castañeda, 2015 & Spain & 2234 & OR & 5.08 (95\% CI 2.22-11.64) & $\begin{array}{l}\text { Prospective } \\
\text { study }\end{array}$ \\
\hline Queiro, 2018 & Spain & 340 & OR & $2.80(95 \%$ CI $1.7-4.3)$ & $\begin{array}{l}\text { Cross- } \\
\text { sectional }\end{array}$ \\
\hline Kibari, 2019 & Israel & 34,771 & OR & $1.48(95 \%$ CI $1.36-1.61)$ & $\begin{array}{l}\text { Cross- } \\
\text { sectional }\end{array}$ \\
\hline \multirow[t]{2}{*}{ Dreiher, 2013} & Israel & 1647 & OR & $1.60(95 \%$ CI $1.02-2.52)$ in females & $\begin{array}{l}\text { Cross- } \\
\text { sectional }\end{array}$ \\
\hline & & 1647 & OR & $0.71(95 \%$ CI $0.42-1.22)$ in males & $\begin{array}{l}\text { Cross- } \\
\text { sectional }\end{array}$ \\
\hline Tam, 2008 & $\begin{array}{l}\text { Hong } \\
\text { Kong }\end{array}$ & 185 & OR & 9.27 (95\% CI 2.09-41.09) & $\begin{array}{l}\text { Cross- } \\
\text { sectional }\end{array}$ \\
\hline Kaine, 2019 & US & 49,935 & HR & $1.41(95 \%$ CI $1.27-1.56)$ & $\begin{array}{l}\text { Cross- } \\
\text { sectional }\end{array}$ \\
\hline Charlton, 2018 & UK & 6783 & $\mathrm{RR}$ & $1.40(95 \%$ CI $1.15-1.70)$ & $\begin{array}{c}\text { Prospective } \\
\text { study }\end{array}$ \\
\hline
\end{tabular}

The risk of DM in subjects with PsA is higher compared with subjects without PsA and the OR ranges between 1.48 in Israel and 9.27 in Hong Kong, respectively [22-24, 27-31] (Table 2).

The more elevated prevalence of DM in PsA population is in North America, which could be partially explained by the high rates of obesity and unhealthy lifestyles in the general population [25]. The study by Dreiher et al. analyzed the difference between males and females patients affected by PsA about the risk of DM. Females in PsA group had a prevalence of DM of $18.7 \%(10.3 \%$ of the control group) with OR 1.60 (95\% CI 1.02-2.52) while in males there was the same prevalence of DM (11.2\%) in PsA group and in control group with OR 0.71 (95\% CI 0.42-1.22). In this study, the association between PsA and DM was noted only among women. For this reason, the authors suggested that women with PsA may be better candidates for DM screening [29]. Some factors predictive of developing of DM were also analyzed by Eder et al. They found tender joint count with HR 1.53 (95\% CI 1.08-2.18) and erythrocyte sedimentation rate with HR 1.21 (95\% CI 1.03-1.41) predicted the development of DM. These data indicate that patients with elevated disease activity have a higher risk of developing DM [27]. In a cross-sectional study, Queiro et al. found that in patients with late psoriasis onset (after the age of 40 years) and PsA DM was significantly more frequent with OR 8.2 (95\% CI 1.9-12.4). These data suggest that DM risk should be carefully evaluated in patients with PsA whose psoriasis begins after 40 years of age [24]. These data globally show the higher prevalence of DM in patients with PsA compared to the general population. More in detail, 
the risk of DM appears to be higher for women and for those patients with more active disease, and thus the need to actively screen for DM these special populations.

Also, the association between PsO and DM is well known. Most of the patients with PsA also have PsO and only in a few cases is PsA not associated with skin manifestations. For this reason, it is difficult to split these two conditions, but in some studies patients with $\mathrm{PsO}$ and PsA were analyzed separately. The prevalence of DM in PsA ranges from 6.1 to $7.8 \%$ compared to PsO 5.5-6.3\% $[22,32]$ with an incidence rate of DM in PsA of 7.3 per 1000 patient-years and PsO of 6.4 [33]. Both PsA and PsO have been associated with insulin resistance and $\mathrm{DM}$, but these studies suggest a bit stronger association between PsA and DM rather than between PsO and DM. Inflammation of both skin and joints seems to have an influence on glucose metabolism. Nevertheless, the involvement of joints and enthesis, which is characteristic of PsA, is related to the most significative effect on glucose metabolism.

To the best of our knowledge, DM as a risk factor for PsA has not been investigated, moreover there are no studies on the impact of DM on PsA disease activity and clinical outcome. Some studies investigate DM as a risk factor for musculoskeletal diseases including flexor tenosynovitis, osteoarthritis, carpal tunnel syndrome, adhesive capsulitis, diffuse idiopathic skeletal hyperostosis, neuropathic osteoarthropathy, diabetic muscle infarction, Dupuytren's contracture, crystal induced arthritis, and reflex sympathetic dystrophy [34-36]. In recent multicentric cross-sectional studies investigating the association between comorbidities and quality of life in PsA patients, they found that anxiety was independently associated with impairment of quality of life, but DM had no significant effect $[37,38]$. Fowler et al. reported that psoriatic patients with comorbidities such as DM incur into greater indirect costs from work loss than patients without any co-morbidity but specific data in patients with PsA are not available [39].

\section{PATHOGENIC MECHANISMS LINKING PSORIATIC ARTHRITIS AND DIABETES MELLITUS}

The underlying pathways linking PsA to DM are complex and not fully understood. However, identification of the pathophysiologic mechanisms linking these two diseases is important for clinical practice because it may offer novel pharmacologic approaches. In more detail, the insulin receptor has an intrinsic tyrosine kinase activity. Binding of insulin to its receptor induces both autophosphorylation and phosphorylation of tyrosine residues on insulin receptor substrate (IRS)-1 to IRS-4 proteins, thus initiating the intracellular signaling cascade. The two major pathways of insulin signaling are the phosphatidylinositol 3-kinase (PI-3 kinase) and the mitogen-activated protein (MAP) kinase. The PI-3 kinase pathway is initiated by tyrosine phosphorylation and results in the activation of Akt and other downstream effector molecules that mediate the metabolic response to insulin; this includes, among others, the translocation of the glucose transporter 4 (GLUT4) to the membrane. On the other hand, the MAP kinase pathway begins with phosphorylation of Shc, Grb2/Sos, and Ras, and results in the activation of extracellular signal-regulated kinase (ERK-1 and 2), regulating the mitogenic and pro-inflammatory responses of insulin signaling [40]. The biochemical basis of insulin resistance in type $2 \mathrm{DM}$ has been the subject of many studies. While the quantitative regulation of the insulin-sensitive glucose transporters (GLUT4) and insulin receptors themselves may contribute to this disorder, these two factors are probably inadequate to explain completely insulin resistance.

In the pathogenesis of PsA, T cells have a key role with an upregulated expression of Toll-like receptor 2 (but not Toll-like receptor 4) and a dominant T-helper-1 (Th1) and Th17 cell responses. In this context, there is an increased production of T-cell-derived cytokines (including TNF- $\alpha$, interferon- $\gamma$, IL-2, IL-17, and granulocyte-macrophage colony-stimulating factor) in the synovial fluid, inducing inflammation of the joints [41-44]. A pathogenetic link between 
PsA and DM could be mediated by cytokines including TNF- $\alpha$, which inhibits the autophosphorylation of the insulin receptor, thus inducing insulin resistance and suppressing the expression of GLUT4. Numerous studies have analyzed the interaction between TNF- $\alpha$ and the insulin signaling pathways. TNF- $\alpha$ decreases insulin-mediated tyrosine phosphorylation of insulin receptor (IR) and inhibits the tyrosine kinase activity of the insulin receptor through IRS- 1 serine phosphorylation (Ser residue 312 in human or 307 in rat) [45], thereby converting IRS-1 into an inhibitor of the insulin receptor [46-49]. In addition, TNF- $\alpha$ promotes the phosphorylation of Ser307 by Jun NH2-terminal kinase (JNK), which inhibits insulin-stimulated tyrosine phosphorylation of IRS-1 in Chinese hamster ovary (CHO) cells [50]. Moreover, TNF$\alpha$ inhibits the activity of PI-3 kinase [51] with the result of suppression of GLUT4 expression by inhibiting the insulin receptor autophosphorylation [52]. TNF- $\alpha$ is also a significant regulator of glucocorticoids metabolism in vivo, increasing the activity of $11 \beta$-hydroxysteroid dehydrogenase 1 (11 $\beta$-HSD1) that converts inactive cortisone to active cortisol. Cortisol contributes to hyperglycemia, causing hepatic gluconeogenesis, and inhibits the peripheral use of glucose (insulin resistance) by decreasing the translocation of glucose transporters (especially GLUT4) to the cell membrane. Treatment with anti-TNF- $\alpha$ therapy leads to a reduction in systemic measures of $11 \beta$-HSD1 activity with the result of lower levels of active cortisol and higher of inactive cortisone [53]. Finally, TNF- $\alpha$ expression is higher in the muscle of subjects with insulin resistance and non-insulin-dependent DM, suggesting an important role for TNF$\alpha$ in the pathogenesis of human insulin resistance (as occurs in obesity and diabetes) [46] and in obese patients TNF- $\alpha$ is secreted in excessive quantities by adipocytes, inhibiting the IR tyrosine kinase in muscle and fat (the two tissues mainly responsible for insulin-stimulated glucose uptake) and promoting insulin resistance [54, 55]. Also, IL-17 is implicated in $\mathrm{DM}$ pathogenesis by activation of the NF- $\mathrm{KB}$ pathway, which up-regulates proinflammatory cytokine gene expression (including IL-1 $\beta$, IL-6, and TNF- $\alpha$ ). These proinflammatory cytokines are known to dampen insulin signaling, leading to insulin resistance and DM development [56].

Another link between PsA and DM could be found in adipokines, a group of cytokines secreted by adipose tissue. Adiponectin is an adipokine with anti-inflammatory, insulin-sensitizing and anti-atherogenic properties, but whose secretion is decreased by proinflammatory cytokines (as TNF- $\alpha$, IL-1 $\beta$, and IL-6) [57]. Some studies have shown that in inflammatory pathologies (as PsA) adiponectin levels are decreased [58] and that anti-psoriatic treatments with anti-TNF- $\alpha$ agents may increase adiponectin levels [59]. Another adipokine is omentin, which is mainly produced by omental and epicardial fat. In psoriasis, serum omentin levels are clearly decreased compared to controls $[60,61]$ and it is downregulated in patients with metabolic syndrome as well $[62,63]$. In the last decade, technological advances have enabled substantial progress in the understanding of disease genetics. Unfortunately, about the genetic link between PsA and DM, studies did not describe an association. More in detail, a study by Lu et al. analyzed the genetic variants of human leukocyte antigen (HLA), fucosyltransferase 2 (FUT2), ubiquitin conjugating enzyme E2 L3 (UBE2L3), and SH2B adaptor protein 3 (SH2B3) genes, but any difference in the risk of DM between psoriasis cases and controls was observed [64]. About the genes involved in IL-12/23 pathway, a study by Eirís et al. found several associations, but only between DM and the IL12B rs6887695, IL12B rs3212227, and IL23R rs2201841, which are non-psoriasis-risk variants [65].

\section{EFFECTS OF THERAPIES FOR PSORIATIC ARTHRITIS ON DIABETES MELLITUS}

The clinical significance of the association between PsA and type $2 \mathrm{DM}$ is relevant for selecting the treatment for PsA, because some treatments including glucocorticoids, NSAIDs, and cyclosporine could worsen the glycemic homeostasis and/or influence cardiovascular risk factors such as arterial hypertension $[66,67]$. International guidelines for the 
Table 3 Effects on serum glucose and/or insulin sensitivity exerted by systemic therapies for PsA

\begin{tabular}{ll}
\hline Drug class & $\begin{array}{l}\text { Effect on serum glucose } \\
\text { or insulin sensitivity }\end{array}$ \\
\hline Corticosteroids & Worsen \\
Methotrexate & Neutral \\
NSAIDs & Neutral/improved \\
Leflunomide & Neutral \\
Sulfasalazine & Neutral \\
Anti-TNF- $\alpha$ & Neutral/improved \\
Anti-IL-12/23 & Neutral \\
Anti-IL-17A & Neutral \\
Apremilast & Neutral/improved \\
\hline
\end{tabular}

treatment of PsA proposed by the European League Against Rheumatism (EULAR) and the Group for Research and Assessment of Psoriasis and Psoriatic Arthritis (GRAPPA) recommend therapies with different mechanisms of action including intra-articular glucocorticoids, methotrexate, anti-TNF- $\alpha$, anti-IL-17 agents, and apremilast. Although systemic corticosteroids are not included in any guidelines, their prescription for PsA is still common in real life [68]. The effects on serum glucose and/or insulin sensitivity exerted by systemic therapies for PsA are discussed (Table 3).

\section{Glucocorticoids}

Glucocorticoids act on multiple pathways, including pancreatic $\beta$-cells function (sensitivity to glucose and ability to release insulin) and insulin resistance in other tissues [69]. The effect of glucocorticoids on glucose metabolism is well known and steroid-induced or steroidexacerbated DM as well [70]. The risk of glucocorticoid-induced DM is more elevated in patients with older age, higher HbA1c level, and lower eGFR [71]. Patients using long-term lowdose prednisolone have hepatic insulin resistance and reduced peripheral nonoxidative glucose disposal, but no change in insulin secretion. These findings demonstrate that lowdose prednisolone also exerts a deleterious effect on carbohydrate metabolism [72]. These studies implicate the importance of using systemic glucocorticoids at low doses and for short time periods.

\section{Non-steroidal Anti-inflammatory Drugs (NSAIDs) and Disease-Modifying Anti- rheumatic Drugs (DMARDs)}

Patients with mild disease or isolated axial PsA are usually treated with non-steroidal anti-inflammatory drugs (NSAIDs) as the first treatment option. Moreover, they could be associated with other therapies for PsA. NSAIDs have been further studied to be potentially beneficial in the prevention and treatment of diabetic subjects due to their action on glucose metabolism; more in detail, NSAIDs exert an anti-inflammatory effect on the pancreatic islets, reduce the metabolic clearance of insulin, and reduce the hepatic insulin resistance, leading to an enhanced peripheral glucose uptake and a reduced endogenous glucose production. NSAIDs are associated with some serious adverse effects, including hypertension and cardiovascular diseases [73, 74]. Unfortunately, diabetic patients also have an increased risk of coronary artery disease and NSAIDs also seem to be associated with an increase in such risk. Furthermore, these patients frequently exhibit an impaired renal function and NSAIDs tend to worsen this condition, increasing the risk of renal disease. These adverse effects tend to limit the expectations on the application of NSAIDs in the treatment of DM [75].

Methotrexate is a synthetic folate analog that inhibits DNA synthesis at chemotherapeutic doses, but that at lower doses exerts anti-inflammatory effects by several mechanisms [76]. Methotrexate in PsA patients does not appear to have hyperglycemic effects and can be safely used in patients with DM. In a study by Dehpouri et al., the use of methotrexate was not associated to a significant alteration in $\mathrm{HbA1c}$ or fasting blood glucose (FBG) levels in patients with PsA [77]. A small retrospective cohort study of patients affected by DM and rheumatologic diseases treated with methotrexate found no significant change in HbA1c before and after treatment 
[78]. In another study on psoriatic patients, Gisondi et al. demonstrated that in patients treated with methotrexate there was no change in the FBG after 6 months of therapy [79]. In a retrospective cohort study among 121,280 patients with a diagnosis of either RA or psoriasis, the cohort treated with methotrexate exhibited a lower risk of new-onset DM compared with those receiving other non-biologic disease-modifying antirheumatic drugs with an adjusted HR for DM of 0.77 (95\% CI 0.53-1.13) [80]. In a retrospective cohort study on 84,989 patients, Chen et al. found an adjusted HR 0.35 (95\% CI 0.28-0.43) for DM in patients with psoriasis or PsA treated with methotrexate, which indicate a protective effect of this therapy against DM [81]. These studies suggest that methotrexate does not impair glucose homeostasis in patients with DM. However, methotrexate is associated with a significant increased risk of liver fibrosis in patients with DM compared to the group without DM [82].

Leflunomide is an inhibitor of pyrimidine synthesis that is used for PsA and several rheumatologic diseases. In murine models, leflunomide was capable of controlling hyperglycemia and improving insulin sensitivity [83] and had a protective effect on renal lesions of diabetic nephropathy [84]. There is no evidence that leflunomide could impair glucose homeostasis.

Finally, sulfasalazine is a compound with sulfonamide and salicylate moieties that exerts anti-inflammatory effects by multiple mechanisms. One study identified patients with DM who had taken sulfasalazine and found that their HbA1c values were lower when taking the drug, concluding that sulfasalazine has glucoselowering effects. However, hemolysis was not evaluated in these patients, making it impossible to determine whether the reduced HbA1c reflected hemolysis or a true change in blood glucose [85]. There are no other specific warnings for diabetic patients treated with sulfasalazine, except hemolysis.

\section{Anti-TNF- $\alpha$ Agents}

In the last two decades, new biotechnological molecules have been used to treat rheumatologic disorders, especially anti-TNF- $\alpha$ agents. The long-term effects of anti-TNF- $\alpha$ treatment on insulin sensitivity are controversial. Studies on patients with PsA or PsO, after the treatment with anti-TNF- $\alpha$ (adalimumab, infliximab and etanercept) up to 6 months, found that the mean of glucose levels remained unchanged [86, 87]. Another study by Stanley et al. showed that FBG decreased significantly in the group treated with etanercept for 6 months compared to the placebo group (change FBG $10.8 \pm 4.4 \%, p=0.02$ ) [88]. These findings indicate that anti-TNF- $\alpha$ therapy for a period of up to 6 months does not have a negative effect on glucose homeostasis in patients with PsA. In the retrospective cohort study among patients with psoriasis previously cited, patients treated with TNF- $\alpha$ antagonists presented a lower risk of new-onset DM compared to those receiving other non-biologic disease-modifying antirheumatic drugs with an adjusted HR for DM of 0.62 (95\% CI 0.42-0.91) [80]. There are also some case reports and a few case series that highlighted recurrent hypoglycemia and improvement in insulin resistance in patients treated with anti-TNF- $\alpha$ therapies (including etanercept, adalimumab and infliximab) in the setting of underlying DM or metabolic syndrome [89-92]. Preliminary evidence suggests that anti-TNF- $\alpha$ therapies could be safely used in patients with DM and in some cases could improve DM as well.

About the safety of anti-TNF- $\alpha$ therapies, adalimumab could be safely used in diabetic patients because they have the same incidence of adverse events than the control group [87].

\section{Anti-IL-17 and Anti-IL-12/23 Agents}

In the last few years, anti-IL-17A monoclonal antibodies have been approved for PsA. Interestingly enough, some studies have shown increased circulating Th17 cells and elevated secretion of IL-17 by T cells in DM patients [93-95]. Additionally, treatment with anti-IL-17 has an insulin-sensitizing effect due to elevation of serum adiponectin concentration and reduction of serum levels of TNF- $\alpha$ [94]. These results suggest that IL-17 could play a role in the 
pathogenesis of insulin resistance in DM. To the best of our knowledge, only a clinical study on the effects of anti-IL-17 on DM and insulin sensitivity has been conducted. A study by Egeberg et al. on patients treated with ixekizumab and another one by Gerdes et al. on patients treated with secukinumab (both antiIL-17A agent) found no significant differences in FBG with the placebo $[96,97]$.

Ustekinumab binds the common p40 subunit of IL-12 and IL-23. A study on DM patients found an increase in the pancreatic islets of inflammatory cytokines, including IL-23. This context of inflammation induces oxidative stress in the $\beta$-cells with impaired insulin biosynthesis and secretion [98]. The only study on PsA patients treated with ustekinumab, which evaluated glucose homeostasis, found more elevated FBG values after 24 weeks of treatment [99]. No studies on the effect of IL-23 inhibitors (guselkumab, tildrakizumab and risankizumab) are currently available.

\section{Apremilast}

Apremilast is an oral small molecule used for PsA and psoriasis that inhibits phosphodiesterase-4 (PDE4), an enzyme that regulates intracellular levels of cyclic AMP and thus the synthesis of effector and regulatory cytokines. PDE4C and PDE4D are expressed in pancreatic $\beta$-cells and are thought to control the secretion of insulin [100, 101]. Studies conducted on patients with psoriasis and psoriatic arthritis treated with apremilast found a neutral impact on glucose intolerance [102-105]. A study by Puig et al. compared the effect of apremilast and placebo on HbA1c in 1808 patients with or without concomitant antidiabetic therapies. The authors found a reduction of HbA1c already after 16 weeks of treatment with apremilast; more in detail, the highest improvements have been observed in patients with HbA1c $>6.5 \%$, with or without concomitant antidiabetic drugs, but more data are needed [106]. A study on roflumilast, a PDE4 inhibitor used only for chronic obstructive pulmonary disease, in a randomized, double-blind, placebo-controlled multicenter study found lowered glucose levels after 12 weeks of treatment in DM patients [107].

\section{CONCLUSIONS}

The association between PsA and type $2 \mathrm{DM}$ is clinically relevant because DM is a risk factor for microvascular and macrovascular complications. Patients affected by PsA have a higher prevalence of DM compared to the general population. The more elevated risk of DM is especially in women and for more active PsA. The link between PsA and DM is not fully understood, but some of the principal mediators could be TNF- $\alpha$ and adipokine, especially adiponectin and omentin. Biological therapies for PsA have a neutral effect on glucose homeostasis and could be safely used in patients with DM. It is possible that some new therapies, including apremilast and anti-TNF- $\alpha$, could improve DM based on their mechanism of action, but currently few clinical data are available. Considering glucose homeostasis, methotrexate could be safely used for PsA but it should be prescribed with caution for diabetic patients because it is associated with an increased risk of liver toxicity.

\section{ACKNOWLEDGEMENTS}

Funding. No funding or sponsorship was received for this study or publication of this article.

Authorship. All named authors meet the International Committee of Medical Journal Editors (ICMJE) criteria for authorship for this article, take responsibility for the integrity of the work as a whole, and have given their approval for this version to be published.

Disclosures. Giacomo Dal Bello, Paolo Gisondi, Luca Idolazzi, and Giampiero Girolomoni have nothing to disclose.

Compliance with Ethics Guidelines. This article is based on previously conducted studies 
and does not contain any studies with human participants or animals performed by any of the authors.

Data Availability. Data sharing is not applicable to this article as no datasets were generated or analyzed during the current study.

Open Access. This article is licensed under a Creative Commons Attribution-NonCommercial 4.0 International License, which permits any non-commercial use, sharing, adaptation, distribution and reproduction in any medium or format, as long as you give appropriate credit to the original author(s) and the source, provide a link to the Creative Commons licence, and indicate if changes were made. The images or other third party material in this article are included in the article's Creative Commons licence, unless indicated otherwise in a credit line to the material. If material is not included in the article's Creative Commons licence and your intended use is not permitted by statutory regulation or exceeds the permitted use, you will need to obtain permission directly from the copyright holder. To view a copy of this licence, visit http://creativecommons.org/licenses/by$\mathrm{nc} / 4.0 /$.

\section{REFERENCES}

1. Ogdie A, Weiss P. The epidemiology of psoriatic arthritis. Rheum Dis Clin N Am. 2015;41:545-68.

2. Scotti L, Franchi M, Marchesoni A, Corrao G. Prevalence and incidence of psoriatic arthritis: a systematic review and meta-analysis. Semin Arthritis Rheum. 2018;48:28-34.

3. Calabresi E, Monti S, Governato G, Carli L. One year in review 2018: psoriatic arthritis. Clin Exp Rheumatol. 2019;37:167-78.

4. Vena GA, Altomare G, Ayala F, Berardesca E, Calzavara-Pinton $\mathrm{P}$, Chimenti $\mathrm{S}$, et al. Incidence of psoriasis and association with comorbidities in Italy: a 5-year observational study from a national primary care database. Eur J Dermatol. 2010;20: 593-8.

5. Mease PJ, Gladman DD, Papp KA, Khraishi MM, Thaçi D, Behrens F. Prevalence of rheumatologist- diagnosed psoriatic arthritis in patients with psoriasis in European/North American dermatology clinics. J Am Acad Dermatol. 2013;69:729-35.

6. Khraishi M, Chouela E, Bejar M, Landells I, Hewhook T, Rampakakis E, et al. High prevalence of psoriatic arthritis in a cohort of patients with psoriasis seen in a dermatology practice. J Cutan Med Surg. 2012;16:122-7.

7. Reich K, Kruger K, Mossner R, Augustin M. Epidemiology and clinical pattern of psoriatic arthritis in Germany: a prospective interdisciplinary epidemiological study of 1511 patients with plaquetype psoriasis. Br J Dermatol. 2009;160:1040-7.

8. Ritchlin CT, Colbert RA, Gladman DD. Psoriatic arthritis. N Engl J Med. 2017;376:957-70.

9. Coates LC, Helliwell PS. Psoriatic arthritis: state of the art review. Clin Med. 2017;17:65-70.

10. Fotiadou C, Lazaridou E. Psoriasis and uveitis: links and risks. Psoriasis. 2019;9:91-6.

11. Taylor W, Gladman D, Helliwell P, Marchesoni A, Mease P, Mielants H, CASPAR Study Group. Classification criteria for psoriatic arthritis: development of new criteria from a large international study. Arthritis Rheum. 2006;54:2665-733.

12. Shah K, Paris M, Mellars L, Changolkar A, Mease PJ. Real-world burden of comorbidities in US patients with psoriatic arthritis. RMD Open. 2017;3: e000588.

13. Smyth DJ, Howson JM, Payne F, Maier LM, Bailey R, Holland K, et al. Analysis of polymorphisms in 16 genes in type 1 diabetes that have been associated with other immune-mediated diseases. BMC Med Genet. 2006;6(7):20.

14. International Diabetes Federation (IDF). IDF Diabetes Atlas. 6th ed. Brussels: International Diabetes Federation; 2013.

15. Center for Disease Control and Prevention. National Diabetes Statistics Report, 2017. Atlanta: Centers for Disease Control and Prevention, US Department of Health and Human Services; 2017.

16. Yang $\mathrm{H}$, Wei $\mathrm{Y}, \mathrm{He} \mathrm{J}$, et al. Risk factors for gestational diabetes mellitus in Chinese women: a prospective study of 16,286 pregnant women in China. Diabet Med J Br Diabet Assoc. 2009;26: 1099-104.

17. Seshiah V, Balaji V, Kapur A, et al. Pregnancy and diabetes scenario around the world: India. Int J Gynaecol Obstet Off Organ Int Fed Gynaecol Obstet. 2009;104(Suppl 1):S35-38. 
18. International Diabetes Federation. IDF diabetes atlas, 8th edn. Brussels: International Diabetes Federation. 2017. https://www.diabetesatlas.org. Accessed 30 Sep 2020.

19. Chilelli NC, Burlina S, Lapolla A. AGEs, rather than hyperglycemia, are responsible formicrovascular complications in diabetes: a 'glycoxidation-centric' point of view. Nutr Metab Cardiovasc Dis. 2013;23: 913-9.

20. Nguyen DV, Shaw LC, Grant MB. Inflammation in the pathogenesis of microvascular complications in diabetes. Front Endocrinol. 2012;3:170.

21. Huang D, Refaat M, Mohammedi K, Jayyousi A, Al Suwaidi J, Abi KC. Macrovascular complications in patients with diabetes and prediabetes. Biomed Res Int. 2017;2017:7839101.

22. Charlton R, Green A, Shaddick G, Snowball J, Nightingale A, Tillett $W$, et al. Risk of type 2 diabetes and cardiovascular disease in an incident cohort of people with psoriatic arthritis: a population-based cohort study. Rheumatology (Oxford). 2019;58:144-8.

23. Castañeda S, Martín-Martínez MA, González-Juanatey C, Llorca J, García-Yébenes MJ, Pérez-Vicente $\mathrm{S}$, et al. Cardiovascular morbidity and associated risk factors in Spanish patients with chronic inflammatory rheumatic diseases attending rheumatology clinics: baseline data of the CARMA Project. Semin Arthritis Rheum. 2015;45:7-8.

24. Queiro R, Lorenzo A, Pardo E, Brandy A, Coto P, Ballina J. Prevalence and type II diabetes-associated factors in psoriatic arthritis. Clin Rheumatol. 2018;37:1059-64.

25. Husni ME. Comorbidities in psoriatic arthritis. Rheum Dis Clin N Am. 2015;41:677-98.

26. Kaine J, Song X, Kim G, Hur P, Palmer JB. Higher incidence rates of comorbidities in patients with psoriatic arthritis compared with the general population using US. Administrative Claims Data. J Manag Care Spec Pharm. 2019;25:122-32.

27. Eder L, Chandran V, Cook R, Gladman DD. The risk of developing diabetes mellitus in patients with psoriatic arthritis: a cohort study. J Rheumatol. 2017;44:286-91.

28. Kibari A, Cohen AD, Gazitt T, Bitterman H, Lavi I, Feldhamer I, et al. Cardiac and cardiovascular morbidities in patients with psoriatic arthritis: a population-based case control study. Clin Rheumatol. 2019;38:2069-75.
29. Dreiher J, Freud T, Cohen AD. Psoriatic arthritis and diabetes: a population-based cross-sectional study. Dermatol Res Pract. 2013;2013:580404.

30. Tam L-S, Tomlinson B, Chu TTW, Li M, Leung Y-Y, Kwok L-W, et al. Cardiovascular risk profile of patients with psoriatic arthritis compared to controls-the role of inflammation. Rheumatology. 2008;47:718-23.

31. Coto-Segura P, Eiris-Salvado N, González-Lara L, Queiro-Silva R, Martinez-Camblor P, MaldonadoSeral C, et al. Psoriasis, psoriatic arthritis and type 2 diabetes mellitus: a systematic review and metaanalysis. Br J Dermatol. 2013;169:783-93.

32. Radner H, Lesperance T, Accortt NA, Solomon DH. Incidence and prevalence of cardiovascular risk factors among patients with rheumatoid arthritis, psoriasis, or psoriatic arthritis. Arthritis Care Res (Hoboken). 2017;69:1510-8.

33. Dubreuil M, Rho YH, Man A, Zhu Y, Zhang Y, Love $\mathrm{TJ}$, et al. Diabetes incidence in psoriatic arthritis, psoriasis and rheumatoid arthritis: a UK populationbased cohort study. Rheumatology. 2014;53: 346-52.

34. Burner TW, Rosenthal AK. Diabetes and rheumatic diseases. Curr Opin Rheumatol. 2009;21:50-4.

35. Al-Homood IA. Rheumatic conditions in patients with diabetes mellitus. Clin Rheumatol. 2013;32: 527-33.

36. Lebiedz-Odrobina D, Kay J. Rheumatic manifestations of diabetes mellitus. Rheum Dis Clin N Am. 2010;36:681-99.

37. Husted JA, Thavaneswaran A, Chandran V, Gladman DD. Incremental effects of comorbidity on quality of life in patients with psoriatic arthritis. J Rheumatol. 2013;40:1349-56.

38. Bavière $\mathrm{W}$, Deprez $\mathrm{X}$, Houvenagel E, Philippe $\mathrm{P}$, Deken V, Flipo RM, et al. Association between comorbidities and quality of life in psoriatic arthritis: results from a multicentric cross-sectional study. J Rheumatol. 2019;15:181471.

39. Fowler JF, Duh MS, Rovba L, et al. The impact of psoriasis on health care costs and patient work loss. J Am Acad Dermatol. 2008;59:772-80.

40. White MF, Kahn CR. The insulin signaling system. J Biol Chem. 1994;269:1-4.

41. van Kuijk AW, Reinders-Blankert P, Smeets TJ, Dijkmans BA, Tak PP. Detailed analysis of the cell infiltrate and the expression of mediators of synovial inflammation and joint destruction in the synovium of patients with psoriatic arthritis: 
implications for treatment. Ann Rheum Dis. 2006;65:1551-5.

42. Candia L, Marquez J, Hernandez C, Zea AH, Espinoza LR. Toll-like receptor-2 expression is upregulated in antigen-presenting cells from patients with psoriatic arthritis: a pathogenic role for innate immunity? J Rheumatol. 2007;34:374-9.

43. Veale DJ, Fearon U. The pathogenesis of psoriatic arthritis. Lancet. 2018;391(10136):2273-84.

44. Coates LC, FitzGerald O, Helliwell PS, Paul C. Psoriasis, psoriatic arthritis, and rheumatoid arthritis: is all inflammation the same? Semin Arthritis Rheum. 2016;46:291-304.

45. Aguirre V, Werner ED, Giraud J, Lee YH, Shoelson SE, White MF. Phosphorylation of Ser307 in insulin receptor substrate-1 blocks interactions with the insulin receptor and inhibits insulin action. $\mathrm{J}$ Biol Chem. 2002;277:1531-7.

46. Saghizadeh M, Ong JM, Garvey WT, Henry RR, Kern PA. The expression of TNFalpha by human muscle. Relationship to insulin resistance. J Clin Investig. 1996;97:1111-6.

47. Gupta D, Varma S, Khandelwal RL. Long-term effects of tumor necrosis factor-alpha treatment on insulin signaling pathway in HepG2 cells and HepG2 cells overexpressing constitutively active Akt/PKB. J Cell Biochem. 2007;100:593-607.

48. Hotamisligil GS, Spiegelman BM. Tumor necrosis factor alpha: a key component of the obesity-diabetes link. Diabetes. 1994;43:1271-8.

49. Hotamisligil GS, Peraldi P, Budavari A, Ellis R, White MF, Spiegelman BM. IRS-1-mediated inhibition if insulin receptor tyrosine kinase activity in TNF-alpha- and obesity-induced insulin resistance. Science. 1996;271:665-8.

50. Aguirre V, Uchida T, Yenush L, Davis R, White MF. The c-Jun NH (2)-terminal kinase promotes insulin resistance during association with insulin receptor substrate-1 and phosphorylation of Ser (307). J Biol Chem. 2000;275:9047-54.

51. Kanety H, Feinstein R, Papa MZ, Hemi R, Karasik A. Tumor necrosis factor alpha-induced phosphorylation of insulin receptor substrate-1 (IRS-1). Possible mechanism for suppression of insulin-stimulated tyrosine phosphorylation of IRS-1. J Biol Chem. 1995;270:23780-4.

52. Uysal KT, Wiesbrock SM, Marino MW, Hotamisligil GS. Protection from obesity-induced insulin resistance in mice lacking TNF-alpha function. Nature. 1997;389:610-4.
53. Nanus DE, Filer AD, Hughes B, Fisher BA, Taylor PC, Stewart PM, et al. TNF $\alpha$ regulates cortisol metabolism in vivo in patients with inflammatory arthritis. Ann Rheum Dis. 2015;74:464-9.

54. Hotamisligil GS, Shargill NS, Spiegelman BM. Adipose expression of tumor necrosis factor- $\alpha$ : direct role in obesity linked insulin resistance. Science. 1993;259:87-91.

55. Hotamisligil GS, Budavari A, Murray D, Spiegelman BM. Reduced tyrosine kinase activity of the insulin receptor in obesity-diabetes: central role of tumor necrosis factor- $\alpha$. J Clin Investig. 1994;94:1543-9.

56. Abdel-Moneima A, Bakerya HH, Allam G. The potential pathogenic role of IL-17/Th17 cells in both type 1 and type 2 diabetes mellitus. Biomed Pharmacother. 2018;101:287-92.

57. Wolk K, Sabat R. Adipokines in psoriasis: an important link between skin inflammation and metabolic alterations. Rev Endocr Metab Disord. 2016;17:305-17.

58. Shibata S, Saeki H, Tada Y, Karakawa M, Komine M, Tamaki K. Serum high molecular weight adiponectin levels are decreased in psoriasis patients. J Dermatol Sci. 2009;55:62-3.

59. Shibata S, Tada Y, Hau C, et al. Adiponectin as an anti-inflammatory factor in the pathogenesis of psoriasis: induction of elevated serum adiponectin levels following therapy. Br J Dermatol. 2011;164: 667-70.

60. Turan H, Yaykasli KO, Soguktas H, Yaykasli E, Aliagaoglu C, Erdem T, et al. Omentin serum levels and omentin gene Val109Asp polymorphism in patients with psoriasis. Int J Dermatol. 2014;53: 601-5.

61. Ismail SA, Mohamed SA. Serum levels of visfatin and omentin-1in patients with psoriasis and their relation to disease severity. Br J Dermatol. 2012;167: 436-9.

62. Liu R, Wang X, Bu P. Omentin-1 is associated with carotid atherosclerosis in patients with metabolic syndrome. Diabetes Res Clin Pract. 2011;93:21-5.

63. Shang FJ, Wang JP, Liu XT, Zheng QS, Xue YS, Wang B, et al. Serum omentin-1 levels are inversely associated with the presence and severity of coronary artery disease in patients with metabolic syndrome. Biomarkers. 2011;16:657-62.

64. Lu Y, Chen H, Nikamo P, Qi Low H, Helms C, Seielstad M, Liu J, et al. Association of cardiovascular and metabolic disease genes with psoriasis. J Investig Dermatol. 2013;133:836-9. 
65. Eirís N, González-Lara L, Santos-Juanes J, Queiro R, Coto E, Coto-Segura P. Genetic variation at IL12B, IL23R and IL23A is associated with psoriasis severity, psoriatic arthritis and type 2 diabetes mellitus. J Dermatol Sci. 2014;75:167-72.

66. Lee MS, Chang CH, Lin RY, Lai MS. Risks of hypertension associated with cyclosporine, nonsteroidal anti-inflammatory drugs, and systemic glucocorticoids in patients with psoriasis: a nationwide population-based nested case-control study in Taiwan. Pharmacoepidemiol Drug Saf. 2016;25:133-40.

67. Hugh J, Van Voorhees AS, Nijhawan RI, Bagel J, Lebwohl M, Blauvelt A, Hsu S, Weinberg JM. From the Medical Board of the National Psoriasis Foundation: the risk of cardiovascular disease in individuals with psoriasis and the potential impact of current therapies. J Am Acad Dermatol. 2014;70: 168-77.

68. Aimo C, Cosentino VL, Sequeira G, Kerzberg E. Use of systemic glucocorticoids in patients with psoriatic arthritis by Argentinian and other Latin-American rheumatologists. Rheumatol Int. 2019;39: 723-7.

69. Hwang JL, Weiss RE. Steroid-induced diabetes: a clinical and molecular approach to understanding and treatment. Diabetes Metab Res Rev. 2014;30: 96-102.

70. Angelopoulos TP, Tentolouris NK, Bertsias GK, Boumpas DT. Steroid-induced diabetes in rheumatologic patients. Clin Exp Rheumatol. 2014;32: 126-30.

71. Katsuyama T, Sada KE, Namba S, Watanabe H, Katsuyama E, Yamanari T, Wada J, Makino H. Risk factors for the development of glucocorticoid-induced diabetes mellitus. Diabetes Res Clin Pract. 2015;108:273-9.

72. Petersons CJ, Mangelsdorf BL, Jenkins AB, Poljak A, Smith MD, Greenfield JR, et al. Effects of low-dose prednisolone on hepatic and peripheral insulin sensitivity, insulin secretion, and abdominal adiposity in patients with inflammatory rheumatologic disease. Diabetes Care. 2013;36:2822-9.

73. Szeto CC, Sugano K, Wang JG, Fujimoto K, Whittle S, Modi GK, et al. Non-steroidal anti-inflammatory drug (NSAID) therapy in patients with hypertension, cardiovascular, renal or gastrointestinal comorbidities: joint APAGE/APLAR/APSDE/APSH/ APSN/PoA recommendations. Gut. 2020;69:617-29.

74. Marsico F, Paolillo S, Filardi PP. NSAIDs and cardiovascular risk. J Cardiovasc Med (Hagerstown). 2017;18(Suppl 1):e40-43.
75. Bellucci PN, González Bagnes MF, Di Girolamo G, González CD. Potential effects of nonsteroidal antiinflammatory drugs in the prevention and treatment of type 2 diabetes mellitus. J Pharm Pract. 2017;30:549-56.

76. Cronstein BN. Low-dose methotrexate: a mainstay in the treatment of rheumatoid arthritis. Pharmacol Rev. 2005;57:163-72.

77. Dehpouri T, Rahmatpour Rokni G, Ahangar Narenjbon N, et al. Evaluation of the glycemic effect of methotrexate in psoriatic arthritis patients with metabolic syndrome: a pilot study. Dermatol Rep. 2019;11:7965.

78. Rekedal LR, Massarotti E, Garg R, Bhatia R, Gleeson $\mathrm{T}$, Lu B, et al. Changes in glycosylated hemoglobin after initiation of hydroxychloroquine or methotrexate treatment in diabetes patients with rheumatic diseases. Arthritis Rheum. 2010;62: 3569-73.

79. Gisondi P, Cotena C, Tessari G, Girolomoni G. Anti-tumour necrosis factor- $\alpha$ therapy increases body weight in patients with chronic plaque psoriasis: a retrospective cohort study. J Eur Acad Dermatol Venereol. 2008;22:341-4.

80. Solomon DH, Massarotti E, Garg R, Liu J, Canning C, Schneeweiss S. Association between diseasemodifying anti-rheumatic drugs and diabetes risk in patients with rheumatoid arthritis and psoriasis. JAMA. 2011;305:2525-31.

81. Chen HH, Chen DY, Lin CC, Chen Y-M, Lai KL, Lin $\mathrm{CH}$. Association between use of disease-modifying antirheumatic drugs and diabetes in patients with ankylosing spondylitis, rheumatoid arthritis, or psoriasis/psoriatic arthritis: a nationwide, population-based cohort study of 84,989 patients. Ther Clin Risk Manag. 2017;13:583-92.

82. Montaudié H, Sbidian E, Paul C, Maza A, Gallini A, Aractingi S, et al. Methotrexate in psoriasis: a systematic review of treatment modalities, incidence, risk factors and monitoring of liver toxicity. J Eur Acad Dermatol Venereol. 2011;25(Suppl 2):12-8.

83. Chen J, Sun J, Doscas ME, Ye J, Williamson AJ, Li Y, et al. Control of hyperglycemia in male mice by leflunomide: mechanisms of action. J Endocrinol. 2018;237:43-58.

84. Zhang Q, Ji Y, Lv W, He T, Wang J. Protective effects of leflunomide on renal lesions in a rat model if diabetic nephropathy. Ren Fail. 2016;38:124-30.

85. Haas RM, Li P, Chu JW. Glucose-lowering effects of sulfasalazine in type 2 diabetes. Diabetes Care. $2005 ; 28: 2238-9$. 
86. da Silva BS, Bonfá E, de Moraes JC, Saad CG, Ribeiro AC, Gonçalves CR, et al. Effects of anti-TNF therapy on glucose metabolism in patients with ankylosing spondylitis, psoriatic arthritis or juvenile idiopathic arthritis. Biologicals. 2010;38:567-9.

87. Kimball AB, Bensimon AG, Guerin A, Yu AP, Wu EQ, Okun MM, et al. Efficacy and safety of adalimumab among patients with moderate to severe psoriasis with co-morbidities: subanalysis of results from a randomized, double-blind, placebo-controlled, phase III trial. Am J Clin Dermatol. 2011;12: 51-62.

88. Stanley TL, Zanni MV, Johnsen S, et al. TNF-antagonism with etanercept decreases glucose and increases the proportion of high molecular weight adiponectin in obese subjects with features of the metabolic syndrome. J Clin Endocrinol Metab. 2011;96:e146-150.

89. Yazdani-Biuki B, Stelzl H, Brezinschek H, et al. Improvement of insulin sensitivity in insulin resistant subjects during prolonged treatment with the anti-TNF- $\alpha$ antibody infliximab. Eur J Clin Investig. 2004;34:641-2.

90. Cheung D, Bryer-Ash M. Persistent hypoglycemia in a patient with diabetes taking etanercept for the treatment of psoriasis. J Am Acad Dermatol. 2009;60:1032-6.

91. Pfeifer EC, Saxon DR, Janson RW. Etanercept-induced hypoglycemia in a patient with psoriatic arthritis and diabetes. J Investig Med High Impact Case Rep. 2017;5:1-4.

92. Bonilla E, Lee YY, Phillips PE, Perl A. Hypoglycaemia after initiation of treatment with etanercept in a patient with type 2 diabetes mellitus. Ann Rheum Dis. 2007;66:1688.

93. Jagannathan-Bogdan M, McDonnell ME, Shin $H$, Rehman Q, Hasturk H, Apovian CM, Nikolajczyk BS. Elevated pro-inflammatory cytokine production by a skewed $\mathrm{T}$ cell compartment requires monocytes and promotes inflammation in type 2 diabetes. J Immunol. 2011;186:1162-72.

94. Ohshima K, Mogi M, Jing F, Iwanami J, Tsukuda K, Min LJ, Higaki J, Horiuchi M. Roles of interleukin 17 in angiotensin II type 1 receptor-mediated insulin resistance. Hypertension. 2012;59:493-9.

95. Zhang C, Xiao C, Wang P, Xu W, Zhang A, Li Q, Xu $X$. The alteration of Th1/Th2/Th17/Treg paradigm in patients with type 2 diabetes mellitus: relationship with diabetic nephropathy. Hum Immunol. 2014;75:289-96.

96. Egeberg A, Wu JJ, Korman N, Solomon JA, Goldblum O, Zhao F, Mallbris L. Ixekizumab treatment shows a neutral impact on cardiovascular parameters in patients with moderate-to-severe plaque psoriasis: Results from UNCOVER-1, UNCOVER-2, and UNCOVER-3. J Am Acad Dermatol. 2018;79: 104-9.

97. Gerdes S, Pinter A, Papavassilis C, Reinhardt M. Effects of secukinumab on metabolic and liver parameters in plaque psoriasis patients. J Eur Acad Dermatol Venereol. 2020;34:533-41.

98. Hasnain SZ, Borg DJ, Harcourt BE, Tong H, Sheng YH, Ng CP, Das I, Wang R, Chen AC, Loudovaris T, Kay TW, Thomas HE, Whitehead JP, Forbes JM, Prins J, McGuckin MA. Glycemic control in diabetes is restored by therapeutic manipulation of cytokines that regulate beta cell stress. Nat Med. 2014;20: 1417-26.

99. Ng CY, Tzeng IS, Liu SH, Chang YC, Huang YH. Metabolic parameters in psoriatic patients treated with interleukin-12/23 blockade (ustekinumab). J Dermatol. 2018;45:309-13.

100. Heimann E, Jones HA, Resjo S, Manganiello VC, Stenson L, Degerman E. Expression and regulation of cyclic nucleotide phosphodiesterases in human and rat pancreatic islets. PLoS One. 2010;5:e14191.

101. Pyne NJ, Furman BL. Cyclic nucleotide phosphodiesterases in pancreatic islets. Diabetologia. 2003;46: 1179-89.

102. Papp K, Reich K, Leonardi CL, et al. Apremilast, an oral phosphodiesterase- 4 inhibitor, in patients with moderate to severe plaque psoriasis: results of a phase III, randomized, controlled trial (ESTEEM 1). J Am Acad Dermatol. 2015;73:37-49.

103. Paul C, Cather J, Gooderham M, et al. Efficacy and safety of apremilast, an oral phosphodiesterase 4 inhibitor, in patients with moderate-to-severe plaque psoriasis over 52 weeks: a phase III, randomized controlled trial (ESTEEM 2). Br J Dermatol. 2015;173:1387-99.

104. Gisondi P, Fostini AC, Fossà I, Girolomoni G, Targher G. Psoriasis and the metabolic syndrome. Clin Dermatol. 2018;36:21-8.

105. Dattola A, Del Duca E, Saraceno R, Gramiccia T, Bianchi L. Safety evaluation of apremilast for the treatment of psoriasis. Expert Opin Drug Saf. 2017;16:381-5.

106. Puig L, Korman N, Greggio C, Cirulli J, Teng L, Chandran $\mathrm{V}$, et al. Long-term hemoglobin A1c changes with apremilast in patients with psoriasis and psoriatic arthritis: pooled analysis of phase 3 ESTEEM and PALACE trials and phase 3b LIBERATE trial. J Am Acad Dermatol. 2019;81:89. 
107. Wouters EF, Bredenbroker D, Teichmann P, et al. Effect of the phosphodiesterase 4 inhibitor roflumilast on glucose metabolism in patients with treatment-naive, newly diagnosed type 2 diabetes mellitus. J Clin Endocrinol Metab. 2012;97: e1720-1725. 